Abstracta Iranica Abstracta Iranica

Revue bibliographique pour le domaine irano-aryen

Volume 29 | 2008

Comptes rendus des publications de 2006

\title{
"Medical aspects of the encounter between Greece and the Persian Empire ». IA, 41, 2006, pp. 119-125.
}

\section{Rémy Boucharlat}

\section{(2) OpenEdition}

1 Journals

\section{Édition électronique}

URL : http://journals.openedition.org/abstractairanica/25682

DOI : $10.4000 /$ abstractairanica. 25682

ISSN : 1961-960X

Éditeur :

CNRS (UMR 7528 Mondes iraniens et indiens), Éditions de l'IFRI

\section{Édition imprimée}

Date de publication : 15 mai 2008

ISSN : 0240-8910

\section{Référence électronique}

Rémy Boucharlat, « « Medical aspects of the encounter between Greece and the Persian Empire ». IA, 41, 2006, pp. 119-125. », Abstracta Iranica [En ligne], Volume 29 | 2008, document 65, mis en ligne le 15 septembre 2008, consulté le 26 septembre 2020. URL : http://journals.openedition.org/ abstractairanica/25682 ; DOI : https://doi.org/10.4000/abstractairanica.25682

Ce document a été généré automatiquement le 26 septembre 2020.

Tous droits réservés 


\title{
« Medical aspects of the encounter between Greece and the Persian Empire ». IA, 41, 2006, pp. 119-125.
}

\author{
Rémy Boucharlat
}

Dans ce court article, l'A. liste quelques plantes médicinales que les Grecs auraient connues par l'empire perse, comme l'indique le qualificatif de mède ou, plus souvent, perse. Parmi les études qui ont déjà été consacrées à ce sujet, l'A. semble ignorer les importants travaux de S. Amigues, spécialiste reconnue de la botanique antique.

INDEX

Thèmes : 3.2.2. Pré-Achéménides et Achéménides

\section{AUTEURS}

RÉMY BOUCHARLAT

CNRS - Lyon 